\title{
افتتاحية استثنائية : مرثية الفارس النبيل
}

بقلم نائب رئيس التحرير

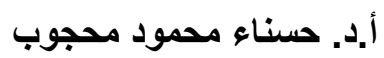

عنوان هذه الافتتاحية كتبه الأستاذ الدكتور شعبان خليفة ـ رحمـه الله - فى افتتاحية عدد اكتوبر -

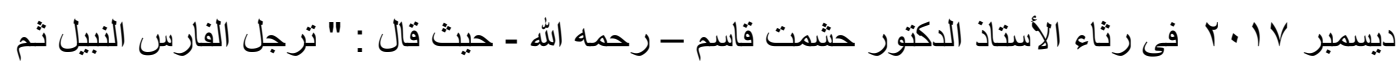
رحل " رين

\section{ونحن بدورنا نقولها عنه : " ترجل الفارس النبيل الجليل الفريد ثم رحل "}

إن القلم يتعثر فى يدى ويأبى الكتابـة ، ومشـاعر الحزن تتأجج داخلى فلم أكن أتمنى أن أكتب هذه

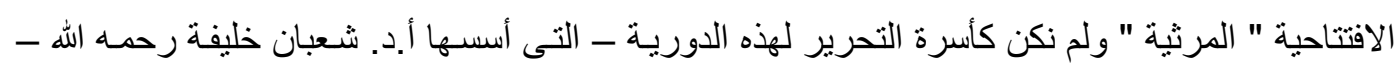

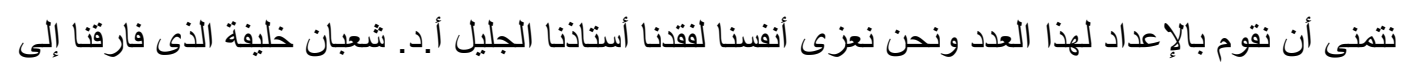
الأبد بعد رحلة عطاء واخلاص ليس لها نظير.

هو فارس نبيل وجليل وفريد بكل ما تعنيه هذه الكلمات لأنه نموذج متفرد لن يتكرر ، و أحد أسـاطين

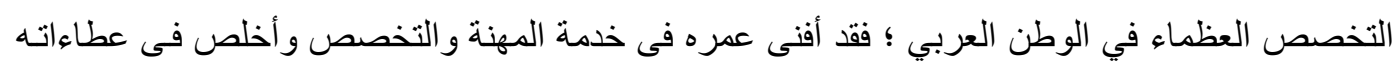
لهذا التخصص ولثباب هذا التخصص ، وقد تنوعت عطاءاته بين التدريس و الإشر اف العلمى والانتاج

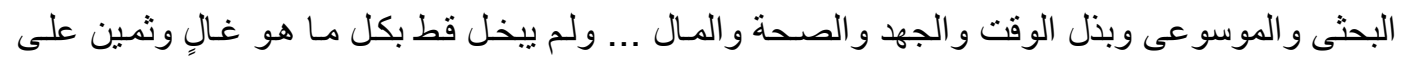

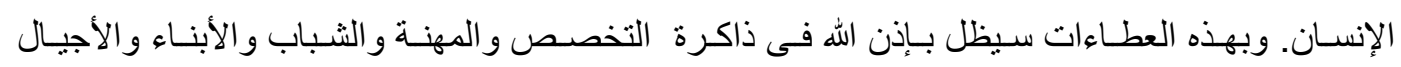
المتعاقبة المنتمية إلى هذه المهنة العظيمة .

و إذا كان هناك أنـاس استفادوا من انتسابهر وعملهم فى مهنة المكتبات و المعلومـات ، و هنـاك أيضـا

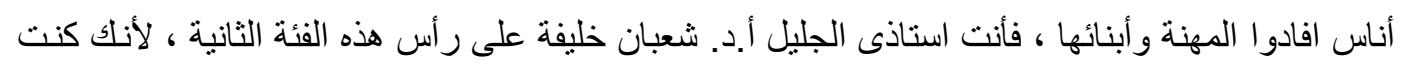

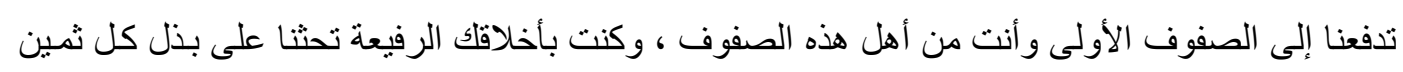

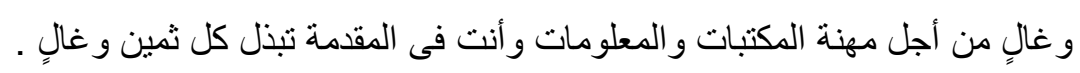
إن الموت حق وهو نهاية كل البشر ولكنتا سنظل نردد : مات قوم وما ماتت مكارمهم

وعاش قوم وهم فى الناس أموات 


$$
\text { ولا نقول فى النهاية إلا ما يرضى الله ورسوله }
$$

إن العين لتدمع و إن القلب ليحزن و إنا على فر اقلك يا أستاذنا الجليل الدكتور شعبان خليفة لمحزونون ؛

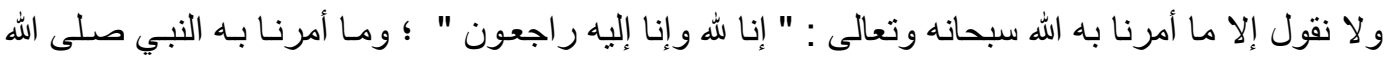

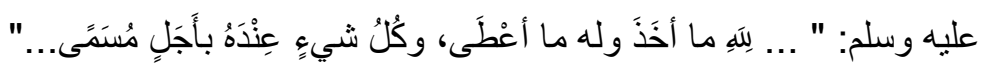
و عزاؤنـا الوحيد يـا استاذى الفاضل أنك تركت تلاميذ يتعهدون للك بالسير على دربك وينهجون مدرسناك ويدعون للك بالرحمة والمغفرة و أن يسكنك الله فسيح جناته ويلهمنا جميعا الصبر و السلو ان . إن أقل القليل الذى يمكن أن نهديه كأسرة تحرير هذه الدوريـة العلميـة إلى روحك الطـاهرة أستاذنا الفاضل تخليدا لذكر الك العطرة هو قيامنا بالتالى : اـ تغيير الغلاف الخارجى ليتم وضع صورتك واسمك كمؤسس لهذه الدوريـة ورئيس تحرير هـا منذ تأسيسها وحتى وفاتكا

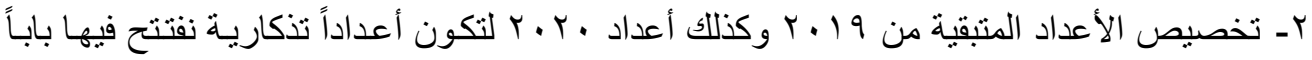
جديدا تحت اسم "فالو ا عن الأستاذ الدكتور شعبان خليفة " وذللك لاتاحسة الفرصـة لمعظم الزملاء و التلاميذ و الأهل لكتابة ما يجيش بصدور هم من مشاعر وأحاسيس ودعوات للك ، فضـلاً عن ذكرياتهم الطيبة معك لك في مشو ار عطاءك الذي استمر قرابة قرن من الزمان .. وبما لا يوثر فى الوقت نفسه ذللك على الدراسـات و البحوث التى تمت المو افقة على نشر ها فى هذه الأعداد r- سوف تظهر باقى أعداد المجلد السادس لعام 9 ــ بالافتتاحيات التى أمليتها و أنت على فر اش المرض للأستاذة ندا سمير ـ أحد تلاميذك المخلصين ـ لتكون أخر الافتتاحيات التى كتبتها فى الدوريات

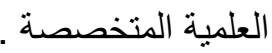
رحمك الله استاذى الجليل وأسكنك فسيح جناته ، وجزاك عنا خيرا وإلههنا الصبر و السلوان 